\title{
THE EFFECT OF FLIPPED LEARNING 3.0 AND SELF- REGULATED LEARNING ON TWELFTH GRADE STUDENTS SPEAKING PERFORMANCE
}

\author{
Agung Krsna Lila Dasa \\ English Language Education, Universitas Pendidikan Ganesha \\ e-mail: krsnalila22@gmail.com \\ Luh Diah Surya Adnyani \\ English Language Education, Universitas Pendidikan Ganesha \\ e-mail: surya.adnyani@undiksha.ac.id \\ Budiarta, L.G.R \\ English Language Education, Universitas Pendidikan Ganesha \\ e-mail: rahayu.budiarta@undiksha.ac.id
}

\begin{abstract}
This study aimed to investigate the effect of flipped learning (FL) 3.0 and self-regulated learning (SRL) on the speaking performance of twelfth-grade students in Buleleng. This study was experimental study that focused on Quasi-Experimental design. The sample was 63 students that classified into the control and experimental class through random sampling to the intact groups. Data were collected from the speaking performance score and questionnaires. The results showed that significant difference of students speaking performance taught by FL 3.0 and conventional method was 0.048 , means that it was significant. Students' speaking performance difference who has low and high SRL was 0.568, means that it was not significant. The interaction effect of FL 3.0 and SRL was 0.790 , means that they had no interaction effect. FL 3.0 could be used in teaching speaking because it had significant effect on students' speaking performance even though the students have high or low SRL.
\end{abstract}

Keywords: flipped learning 3.0, self-regulated learning, speaking performance

\section{INTRODUCTION}

In this fast-paced era technology is very important for all circles. Technology is an important aspect of human life today. Technology is the application of knowledge to the practical aims of human life that includes the use of materials, tools, techniques, and sources of power to make human life easier. The development of technology has a major influence on various aspects of life, one of which is education. In the educational area, technology helps the teacher in teaching and delivering the material to the students. The fast-paced era gives new challenges to the modern teacher, especially for English teachers. English teaching has been changed with the entry of technology (Shyamlee, 2012).

The days of technological developments throughout the world are increasing. The development of technology in Education influences the elements in it. Because technology developing very fast in education, the teacher should know what the appropriate strategy is that should be used in teaching and develop technology-based 
teaching in teaching English. The use of strategies in teaching skills in English certainly has its own goals. Every skill must have the right way, strategy, and treatment so that the target of learning can be achieved. That is why the strategy of learning and technology in teaching should be developed. Flipped learning is one of the English teaching reforms and one of the renewed instructional innovations that potential to transform conventional classes and make them more motivating and interesting in the learning process (Amiryousefi, 2019).

Flipped learning could be implemented in the four skill in learning English (listening, speaking, reading and writing), but sometimes most of EFL students have some problem when they perform speaking in front of the class or when the students talk to the teacher. According to Sarasyifa, (2018), some of the problems experienced by students in learning English, especially speaking English, include the environment that is less supportive to speak English, limited time to practice, differences in students, and the rarely use of the language itself. Besides, in order to teach English especially teaching speaking, the teachers also usually use a conventional way rather than use an innovative way.

The flipped learning or flipped classroom was introduced by Jonathan Bergmann and Aaron Sams for students who had missed class. The implementation of the flipped classroom at that time was using live video recordings and screen casting software to record lectures, demonstrations, and slide presentations with annotations and posted them for the students to watch and read (Singh, Jaswant, Singh, Mohtar, \& Mostafa, 2017).

Flipped learning is a model of learning that switches the activity of learning where the students learn the material or delivered material by the teacher outside of the class and done the assignment in the classroom(Sarasyifa, 2018). Flipped learning makes the interaction more effective among teachers and students and also between students to other students, also flipped learning can make students feel more comfortable and confident asking questions and discussing the issues with the teacher and peers (Evseeva \& Solozhenko, 2015). In flipped learning, the teachers also do not use much time for explaining basic knowledge to the students, because students can use their time before the class to learn those basic bits of knowledge.

Flipped learning developed from its first level until the current level. Flipped Learning is blossoming into its 3.0 era of new innovations and effective implementations. In this development, flipped learning evolves to include global collaboration and innovation. Flipped learning 3.0 is a combination of the use of video and technology in the implementation of flipped learning in the learning process. So, according to (Mennella, n.d.), in this development flipped learning already collaborated and innovated with the global condition.

According to Sarasyifa, (2018), there are several characteristics of flipped learning they are; (a) Flipped Learning switch the learning process from the teacher-centered to students-centered. here the students will be given chance to explore information and try by them-self (b) Flipped learning providing exposure prior to class such as reading from textbook, micro-lecture, or download video from Youtube, Exercise sheet, etc. (c) Flipped learning make a classroom where the teacher is not the "sage on the stage", but the "guide on the side". In other words, the teacher just being the facilitator for the students in the learning process where the teacher is not the main source of the information. 
Flipped learning is an effective way for teachers to teach speaking in English classes especially in the $21^{\text {st }}$ century. This is because reverse learning is an emerging learning model that provides a blend of online learning elements powered by information technology and traditional face-to-face learning elements, which utilize the advantages of online and face-to-face teaching in EFL classes (Li \& Suwanthep, 2017). That means that the Flipped learning model makes it easy for teachers and students in the learning process because the material provided by the teacher can be learned at home by students before they enter the classroom. Form those explanations it could be said that flipped learning is an appropriate way for the teacher to teach speaking for the students.

The effect of flipped learning on students' speaking skills is important to be known, and there is one aspect that indicates successful learning is on the student, it is selfregulated learning (Kız1 \& Savran, 2018). Self-regulated learning is the process where the students activate and sustain knowledge that is systematically oriented toward the achievement of their goals of learning. Self-regulated learning focused on the implementation of self-regulation to issues of learning that make the learners possible to set goals for their learning and then attempt to monitor, regulate, and control their cognition, motivation, and behavior, guided and constrained by their goals (Wolters \& Pintrich, 2003).

Self-regulated learning (SRL) is a learning model that provides opportunities for students to do and control their learning. According to Arianti, (2017) in self-regulated learning, learners must improve their willingness to take responsibility for their own learning. Moreover, students are also directed to be able to learn something in a selfregulated context, such as studying materials or practicing tasks in their handbook on their own. SRL also allows students to manage their learners effectively in their ways to achieve their goal of learning. Self-regulated learning focus on the implementation of self-regulation to issues of learning that make the learners possible to set goals for their learning and then attempt to monitor, regulate, and control their cognition, motivation, and behavior, guided and constrained by their goals (Wolters \& Pintrich, 2003).

According to Pintrich, (2000), Self-regulation consists of four phases, those four phases namely, a) forethought, planning, and activation, b) monitoring, c) control, and d) reaction and reflection. Phase 1 involves planning and setting goals and activating perceptions and knowledge of tasks and contexts in relation to tasks. In phase 2 Pintrich, (2000) explains that phase 2 deals with the monitoring process that represents metacognitive awareness of various aspects of self or tasks and contexts. While for phase 3 involves efforts to control and regulate various aspects of self or tasks and contexts. In the last phase, phase 4 represents a variety of reactions and reflections on the self and the task or context.

Self-regulated learning of students is beneficial for them, because when they have self-regulated learning inside them means that they have will to learn and they know what have to be learnt. Strategy also have effect on students self-regulated learning, appropriate strategy or model make students easier to build their self-regulated learning. Currently, online or blended learning has become ways of teaching that done by teachers because the limited of time for the teacher and students to have face to face learning at school. SRL could be a critical approach to facilitate and improve students' learning effects in online learning (Tsai, Shen, \& Fan, 2013). So, SRL is important had by the students in online or blended learning platform, because they have more time that could be used to learn materials, find related sources for the current material, and practice the material given. 
This study aimed to (a) to know the significant difference on the students' speaking performance taught by flipped learning 3.0 than those who are taught by conventional method on twelfth grade students of SMA N 1 Sukasada, (b) to know the significant difference on the students' speaking performance those who have high self-regulated learning than those who have low self-regulated learning in twelfth grade students at SMA $\mathrm{N} 1$ Sukasada, and (c) to know the interaction effect between flipped learning 3.0 and self-regulated learning.

\section{METHOD}

The design of this study is experimental study which the type of the study used is the Quasi Experimental design. There are two groups in this study they are experimental group and the control group (Fraenkel, Wallen, \& Hyun, 2012). The data were collected in quantitative data. The data in the experimental study will be conducted to collect data on the effect of flipped learning 3.0. The samples of this research are one sample as a control group and one sample as the experimental group. Both of experimental or control class also will be given a questioner to find out whether the students have a high or low level of self-regulated learning. After the post-test data were collected, the data is compiled, processed and analyzed statistically to determine the achievements or treatment results and the differences. The design used in this study is $2 \times 2$ two-way ANOVA.

\section{FINDING AND DISCUSSION}

Based on the results of the speaking test and students' self-regulated learning, a two-way ANOVA calculation renderer table can be arranged to facilitate the analysis of data through the following two-way ANOVA statistical test:

Table 1. ANOVA Presenters Table

\begin{tabular}{|l|l|l|}
\hline \multirow{2}{*}{ Self-regulate } & \multicolumn{2}{|c|}{ Learning Model (A) } \\
\cline { 2 - 3 } & Flipped Learning(A1) & Conventional model (A2) \\
\hline High (B1) & $80,80,80,76,64,76,88,76$, & $68,68,84,68,72,84,80,64$, \\
& $96,64,84,76,68,84,92,80,88$ & $68,72,76,84,72,76,92,88$, \\
& & $80,80,76,80$ \\
\hline Low (B2) & $76,68,68,76,88,84,76,84$, & $76,80,72,60,76,72,76,72$, \\
& $88,80,76,84$ & $76,72,7676,80,72$ \\
\hline
\end{tabular}

The data in the table 1 is processed using SPSS computer program help 23.0 with the two-way ANOVA test, the results obtained are as in table 2. 
Table 2. Two-way ANOVA Test Result

\begin{tabular}{|c|c|c|c|c|c|}
\hline \multicolumn{6}{|c|}{ Tests of Between-Subjects Effects } \\
\hline \multicolumn{6}{|c|}{ Dependent Variable: Score } \\
\hline Source & $\begin{array}{l}\text { Type III Sum of } \\
\text { Squares }\end{array}$ & Df & Mean Square & $\mathrm{F}$ & Sig. \\
\hline Corrected Model & $245.686^{\mathrm{a}}$ & 3 & 81.895 & 1.493 & .226 \\
\hline Intercept & 366152.521 & 1 & 366152.521 & 6674.336 & .000 \\
\hline Model & 223.964 & 1 & 223.964 & 4.082 & .048 \\
\hline SLR & 16.441 & 1 & 16.441 & .300 & .586 \\
\hline Model * SLR & 3.936 & 1 & 3.936 & .072 & .790 \\
\hline Error & 3236.727 & 59 & 54.860 & & \\
\hline Total & 379632.000 & 63 & & & \\
\hline Corrected Total & 3482.413 & 62 & & & \\
\hline
\end{tabular}

The result showed that the significant difference of students speaking performance taught by flipped learning 3.0 and those who were taught by conventional method was 0.048 , which was lower than 0.05 and means that it had a significant difference. The difference of students' speaking performance who had low self-regulated learning and high self-regulated learning was 0.568 , which was higher than 0.05 and means that it did not has significant difference. The interaction effect of flipped learning 3.0 and selfregulated learning was 0.790 , which was higher than 0.05 and means that flipped learning 3.0 and self-regulated learning were not have interaction effect.

Based on statistical tests that have been done, it shows that there is an effect of the use of the flipped learning 3.0 learning model on speaking performance of twelfth grade students of SMA N 1 Sukasada. As for students' self-regulated learning, there is no significant effect on speaking performance, both students who have high self-regulated learning, and students who have low self-regulated learning.

This study shows that there is a significant difference of flipped learning 3.0 on students' speaking skills. It can be seen from the results of the research which shows that there is a significant difference between the experimental class taught using flipped learning 3.0 and the control class taught using conventional methods on students' speaking skills. This is related to the study that was conducted by (Li \& Suwanthep, 2017) The results of students' speaking tests in that study showed that students who were taught by using flipped learning achieved higher and had more improvement in speaking skills compared to groups who were taught by using conventional methods.

These results indicate that teaching methods or learning models can affect students' interest in learning, so that learning models and ways of presenting material can have an impact on students' speaking performance results. In this study, the classroom atmosphere was fun and innovative by emphasizing the use of technology in learning. In the learning process using the flipped learning 3.0 learning model, the teacher uses technology in form of an application that allows the students to learn and can access material anywhere, and also the material presented is more interesting and easily understood by students.

As explained, flipped learning is a learning model that reverses learning where, students learn material at home and do some instructions in class. The concept of flipped learning allows students to be able to receive knowledge anywhere, especially at home 
by watching videos and slides prepared and provided by the teacher, and receiving training in the classroom through the use of some technology. Based on the explanation of (Bergmann \& Sams, 2012) the flipped learning model has the potential to: (a) provide a more dynamic and flexible learning environment where teachers can help students when students have difficulty learning wherever they are; (b) allows students to learn at their own pace; (c) provide opportunities for students to search for and use materials and concepts more broadly, which can contribute to the development of students' communicative competencies; and (d) help students get more involved with learning materials and activities.

In the experimental group, students are trained to get used to using technology and how to communicate in the use of the technology. The use of technology in this study helps teachers to deliver learning material better and students can access the material anytime and anywhere and allows students to communicate with teachers and students when they are not together or face to face. The application of flipped learning 3.0 in this study combines the use of technology and reverse learning models in students where students are given some material and video in the application and they learn the material and video provided at home. Arriving at school, students are ready with the material and videos provided and the teacher only repeats a little and refreshes the material that has been learned and then students are ready to accept assignments or instructions from the teacher.

The implementation of flipped learning 3.0 in this study provides opportunities for students to learn at their own pace and provides opportunities for students to search for and use materials and concepts more broadly, which can contribute to the development of their communicative competence (Xu \& Shi, 2018). Flipped learning makes the interaction more effective because students feel more comfortable and confident asking questions and discussing the material or the problem with the teacher and their friends (Evseeva \& Solozhenko, 2015). Students can look for additional material needed in learning in existing in the application or other sources in accordance with the material being taught. Students can also practice their speaking skills in English based on videos sent via the application and practice their English-speaking skills that they send on application that was watched and commented on by teachers and other students. With the implementation of flipped learning 3.0 students become more involved in the learning process, because all students have the same opportunity to practice their English-speaking skills.

In this study also sought the effect of self-regulated learning on students' speaking skills. The result of this study shows that, there is no significant difference on students speaking performance of students who have high self-regulated learning and those who have low self-regulated learning. It is mean that whether students have high or low selfregulated learning, it does not have significant effect to their speaking performance. From the obtained data, there are several students that have low self-regulated learning got good score in their speaking performance, vice versa, there are also several students that have high self-regulated learning got not so good score in their speaking performance. This result rejects the results of study that conducted by (Antonio et al., 2008) which stated that high level of self-regulated learning lead to higher academic achievement while lower self-regulated learning levels are associated with lower achievement.

From the research conducted also could be seen that sometimes students have a tendency to wait for orders rather than having to set up their own learning activities. This can be seen from even though students have high or low self-regulated learning, it does 
not affect students' achievement in English speaking skills. Besides, basic ability in speaking English is also one of the factors that affect student achievement in speaking English. This basic ability more affects students' ability in speaking English rather than the students' self-regulated learning itself. That is why there is no significant difference between students who have high self-regulated learning and those who have low selfregulated learning.

In this study also found that, there is no interaction effect between flipped learning 3.0 and self-regulated learning on students' speaking performance. This is supported by study that conducted by Paivi Virtanen, Anne Nevgi, (2013). In that study, there is no correlation were found between study success and SRL dimensions. It is mean that, the model or strategy of learning does not have interaction effect with students' self-regulated learning. It could be seen in the result of the speaking test both of the of the experimental and control group. Whether the students have high or low self-regulated learning, it does not affect their learning outcomes. There are students who have high SRL but get low learning scores, and vice versa, there are students who have low SRL but get good scores. The difference is caused more by the basic abilities possessed by the student, not the selfregulated learning that had by the students.

Based on the result of the study and the related theories above, so could be concluded that there is an effect of the implementation of technology that effect students' ability in speaking. The use of technology in this research make learning process more innovative and interesting for the students whether the students have high or low selfregulated learning. The result of this research also indicated that SRL has no significant effect on students' speaking performance even though the students have high or low selfregulated learning. This research may extend to other English skills and not only for speaking skills such as listening, reading, or writing skills. Also, it may extend to other subjects other than English and extend to other objects of the study in other schools in, Buleleng, Bali.

\section{CONCLUSION AND SUGGESTION}

Based on the result of the data analysis in findings and discussion the conclusion could be draw as follows: a) There is significant difference on the students' speaking performance taught by flipped learning 3.0 than those who are taught by conventional method on twelfth grade students of SMA N 1 Sukasada. b) There is no significant difference on the students' speaking performance those who have high self-regulated learning than those who have low self-regulated learning in twelfth grade students at SMA $\mathrm{N} 1$ Sukasada, c) There is no interaction effect between flipped learning 3.0 with selfregulated learning.

The result of study is expected to give innovative model of learning and new experience for students. Students can utilize the knowledge that was gained and technology in the form of applications that was used during this research. For the teacher, the result of this research shows that flipped learning 3.0 can be implemented as the teaching model to teach speaking skill and it is more innovative rather than conventional method which the teacher is become the center of the learning process. So, it is effective teaching media for the teacher to give new treatment for students. Besides, teachers have an important role in supporting the students to do self-regulated learning at school. It can be implemented by minimizing the teacher centered in learning process. Teachers also have to give the students opportunity to find the material and solve the problem by themselves. 


\section{REFERENCES}

Amiryousefi, M. (2019). The Incorporation of Flipped Learning Into Conventional Classes to Enhance EFL learners ' L2 Speaking, L2 Listening, and Engagement. Innovation in $\begin{array}{lllll}\text { Language Learning } & \end{array}$ https://doi.org/10.1080/17501229.2017.1394307

Antonio, V., Núñez Carlos, J., Cabanach, R. G., González-pienda, J. A., Rodríguez, S., Rosário, P., ... Muñoz-cadavid, M. A. (2008). Self-regulated Profiles and Academic Achievement. Psicothema, 20, 724-731.

Arianti, N. M. M. (2017). The Identification of Self-regulated Learning Implemented By The Students of Senior High School in Bulelelng Sub-district.

Bergmann, J., \& Sams, A. (2012). Flip Your Classroom: Reach Every Student in Every Class Every Day.

Evseeva, A., \& Solozhenko, A. (2015). Use of Flipped Classroom Technology in Language Learning. Procedia - Social and Behavioral Sciences, 206(November), 205-209. https://doi.org/10.1016/j.sbspro.2015.10.006

Fraenkel, J. R., Wallen, N. E., \& Hyun, H. H. (2012). How to Design and Evaluate research in Education.

Kızıl, A. Ş., \& Savran, Z. (2018). Assessing self-regulated learning: The case of vocabulary learning through information and communication technologies. Computer Assisted Language Learning ISSN:, 8221. https://doi.org/10.1080/09588221.2018.1428201

Li, S., \& Suwanthep, J. (2017). Integration of Flipped Classroom Model for EFL Speaking. International Journal of Learning and Teaching, 3(2), 118-123. https://doi.org/10.18178/ijlt.3.2.118-123

Mennella, T. (n.d.). Combining Teaching Strategies to Unlock New Possibilities.

Paivi Virtanen, Anne Nevgi, H. N. (2013). Self-regulation in Higher Education: Students' Motivational, and Learning Strategies, and Their Relationships to Study Success. Studies for the Learning Society, 3(1). https://doi.org/10.2478/sls-2013-0004

Pintrich, P. R. (2000). Handbook of Self-Regulation. The University of Michigan, Ann Arbor, Michigan.

Sarasyifa, M. (2018). Applying Flipped Classroom Model to Enhance Students' Speaking Skill. Faculty of Educational Sciences.

Shyamlee, S. D. (2012). "Use of Technology in English Language Teaching and Learning ": An Analysis . 2012 International Conference on Language, Medias and Culture, 33, 150-156.

Singh, H., Jaswant, S., Singh, C. K. S., Mohtar, T. M. T., \& Mostafa, N. A. (2017). A Review of Research on Flipped Classroom Approach for Teaching Communication Skills in English. International Journal of Academic Research in Business and Social Sciences, 7(10). https://doi.org/10.6007/IJARBSS/v7-i10/3362

Tsai, C., Shen, P., \& Fan, Y. (2013). Research trends in self-regulated learning research in online learning environments: A review of studies published in selected journals from 2003 to 2012 Chia-Wen Tsai, Pei-Di Shen and Ya-Ting Fan. British Journal of Educational Technology, 44(5), 107-110. https://doi.org/10.1111/bjet.12017

Wolters, C. A., \& Pintrich, P. R. (2003). Assessing Academic Self-regulated Learning, 2003(March). 
Xu, Z., \& Shi, Y. (2018). Application of Constructivist Theory in Flipped Classroom - Take College English Teaching as a Case Study. Theory and Practice in Language Studies, 8(7), 880-887. 